\title{
Mycoplasma nucleases able to induce internucleosomal DNA degradation in cultured cells possess many characteristics of eukaryotic apoptotic nucleases
}

\author{
Renate Paddenberg ${ }^{1,3}$, Anke Weber ${ }^{2}$, Swantje Wulf ${ }^{1}$ and \\ Hans Georg Mannherz ${ }^{1}$ \\ ${ }^{1}$ Department of Anatomy and Embryology, Ruhr-University, 44780 Bochum, \\ Germany \\ ${ }^{2}$ Institute of Cytobiology and Cytopathology, Philipps-University, 35037 \\ Marburg, Germany \\ ${ }^{3}$ corresponding author: Department of Anatomy and Embryology, Ruhr- \\ University of Bochum, Universitätsstr. 150, 44780 Bochum, \\ Tel: +49 234700 5219; Fax: +49 234709 4474; e-mail: Renate \\ Paddenberg@rz.ruhr-uni-bochum.de
}

Received 3.9.97; revised 16.12.97; accepted 19.1.98 Edited by M. Piacentini

\begin{abstract}
It was previously shown (Paddenberg et al (1996) Eur J Cell Biol 69, 105-119) that cells of established lines like NIH3T3 fibroblasts and the human pancreatic adenocarcinoma $\mathrm{PaTu}$ 8902 line only degrade their chromatin at internucleosomal sites after an apoptotic stimulus when infected with Mycoplasma hyorhinis. In order to distinguish mycoplasma nucleases $\left(\mathrm{M}_{\mathrm{r}} 47-54 \mathrm{kDa}\right)$ from already described eukaryotic apoptotic enzymes, the mycoplasma nucleases were partially purified from serum-free culture supernatants and further characterized. Here we demonstrate directly that the enriched mycoplasma nucleases were able to fragment the DNA of nuclease-negative substrate nuclei at internucleosomal sites. The DNA degradation was accompanied by morphological changes typical of apoptosis like chromatin condensation and margination followed by shrinkage of the nuclei. The biochemical characterization revealed that the mycoplasma nucleases had a neutral to weakly basic $\mathrm{pH}$-optimum. They required both calcium and magnesium in the $\mathrm{mM}$ range for maximal activation and were inhibited by zinc chloride, EGTA and EDTA. In two dimensional zymograms they migrated as three spots with isoelectic points between 8.1 and 9.5. They were not inhibited by monomeric actin. Our data also demonstrate that nuclear extracts prepared from nuclei isolated from Mycoplasma hyorhinis infected cells contained the mycoplasma nuclease activities leading to their internucleosomal DNA-degradation after incubation in the presence of calcium and magnesium.
\end{abstract}

Keywords: apoptosis; DNA fragmentation; endonucleases; Mycoplasma hyorhinis

Abbreviations: DTE, dithioerythritol; DTT, dithiothreitol; IP, isoelectric point; DMEM, Dulbecco's modified Eagle Medium; EGTA, ethylene glycol-bis( $\beta$-aminoethyl ether) $\mathrm{N}, \mathrm{N}, \mathrm{N}, \mathrm{N}^{\prime}$-tetra- acetic acid; PMSF, phenylmethylsulfonyl fluoride; RT, room temperature; IEF, isoelectric focusing

\section{Introduction}

Particular endonuclease(s) are believed to hydrolyse the cellular chromatin during apoptosis at internucleosomal sites (Wyllie, 1980). Because of the action of this enzyme, extracted DNA of apoptosing cells gives the socalled DNAladder after electrophoresis in agarose gels. Considerable efforts have been made to identify the apoptotic endonuclease(s). Cell culture systems are widely used to investigate the morphological and biochemical changes accompanying apoptosis and have also been employed in attempts to identify the apoptotic endonuclease(s). A Ca $\mathrm{Ca}^{2+} / \mathrm{Mg}^{2+}$-dependent endonuclease is considered the most likely candidate for the apoptotic nuclease (Wyllie et al, 1980; Cohen and Duke, 1984; Arends et al, 1990; Peitsch et al, 1993). In addition, nucleases with different ionic requirements have been described (for review see also Peitsch et al, 1993). For example, a $\mathrm{Mg}^{2+}$-dependent, $\mathrm{Ca}^{2+}$-independent endonuclease has been detected in nuclei isolated from the myeloid cell lines P39, HL60 and KG-1 (Kawabata et al, 1993, 1997), and nuclear extracts of the murine fibroblast cell line NIH3T3 exhibit a $\mathrm{Ca}^{2+}$-dependent endonuclease activity (Ucker et al, 1992).

The existence of two different regulatory mechanisms have been proposed for the apoptotic endonuclease: (i) Internucleosomal DNA degradation is blocked by inhibition of protein synthesis indicating that the expression of the nuclease - or regulatory factors - occurs only after induction of apoptosis (Cohen and Duke, 1984; Martin et al, 1988); (ii) DNA fragmentation takes place even in the presence of inhibitors of protein synthesis (Martin et al, 1990; Martin, 1993). In this case, the nuclease is assumed to be constitutively expressed, but kept somehow in a 'harmless' state possibly by storage in extranuclear compartments or within the nucleus by complexation with yet unknown inhibitory factors. Apoptotic DNA fragmentation would be the result of a translocation or activation process of the enzyme. In both cases the apoptotic nuclease is synthesized by the cell undergoing apoptosis.

However, we have recently shown that nucleases catalysing an internucleosomal DNA degradation can also be provided by contaminating mycoplasmas - cell wall-free bacteria of the class Mollicutes - when using established cell lines. If this is the case, the expression of these nucleases is not suppressed by inhibitors of eukaryotic protein synthesis, but by inhibitors of prokaryotic protein synthesis (Paddenberg et al, 1996).

Contamination of cell cultures with mycoplasmas is not a negligible phenomenon. Whereas in the beginning of the 
eighties contamination rates of about $15 \%$ have been published (McGarrity, 1982; Lang, 1985), at present rates of up to $85 \%$ have been estimated due to more sensitive detection systems (Rottem and Barile, 1993; Rawadi and Dussurget, 1995). This means that an alarming high number of laboratories either works unwittingly with cell cultures contaminated with mycoplasmas or just takes no notice of this fact.

One class of proteins synthesized by mycoplasmas are endonucleases. Up to now, very little is known about these enzymes. Since mycoplasmas lack the biosynthetic capacity for de novo synthesis of nucleotide precursors, it has been proposed that they use these nucleases to acquire precursors for DNA synthesis. Localization studies have revealed that DNA degrading activities can remain associated with the membrane of intact bacteria (Minion et al, 1993) or they can be secreted into the extracellular space (Tyron and Baseman, 1992).

Nucleases in the molecular mass range of $47-54 \mathrm{kd}$ have previously been detected in supernatants, cell homogenates and nuclear extracts of cultures of the human pancreatic adenocarcinoma cell line PaTu 8902 infected with $M$. hyorhinis (Paddenberg et al, 1996). In contrast, non-infected cultures were nuclease negative. Here we extended our previous study and demonstrated directly that partially purified mycoplasma endonucleases were able to cleave the chromatin of substrate nuclei at internucleosomal sites. To this aim, the mycoplasma nucleases were further purified from serum-free supernatants by ion-exchange chromatography. When incubated with nuclei isolated from non-infected cells, the enriched endonucleases induced the formation of a DNA ladder and morphological alterations typical of apoptosis like DNA condensation and margination at the nuclear periphery followed by shrinkage of the nuclei. The enriched mycoplasma endonucleases were further characterized in order to facilitate their distinction from eukaryotic apoptotic nucleases.

\section{Results}

\section{Comparison of the nuclease activities in supernatants, cell homogenates and nuclear extracts of Mycoplasma hyorhinis-infected PaTu 8902 cells}

In cell cultures, most mycoplasma species - M. hyorhinis inclusive - grow as surface parasites which are attached to the plasma membrane of the host cell by adhesins (Razin and Jacobs, 1992). Under these conditions, mycoplasmas are able to produce relative large amounts of nucleases. Using the zymogram technique, cell homogenates, nuclear extracts and culture supernatants of $M$. hyorhinis-free and -infected cultures of the human pancreatic adenocarcinoma cell line PaTu 8902 were used to compare the distribution of these nuclease activities (Figure 1A). In order to distinguish bands caused by nuclease catalysed DNA-degradation from those due to mere DNA-binding, the zymogram gels were soaked in $1 \%$ SDS and subsequently restained with ethidium bromide (Figure 1B). Using this technique, a number of weak bands in the range of $35-40 \mathrm{kDa}$, which were detected in all cell homogenates and nuclear extracts, were identified as being caused by DNA-binding proteins. However, none of the

A

\section{zymogram}

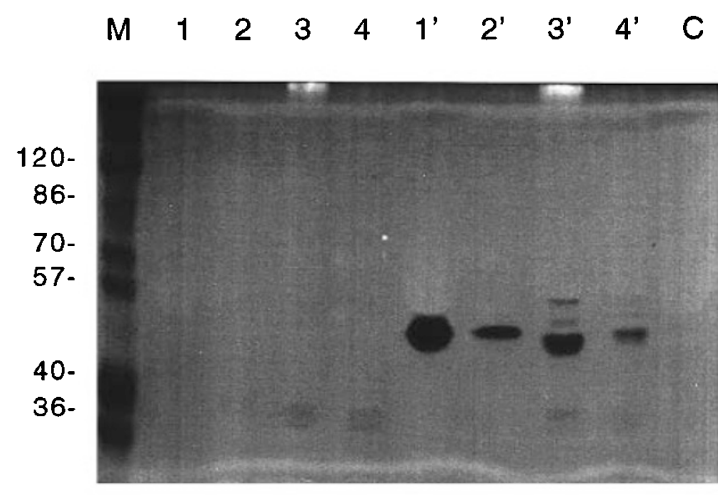

B

\section{zymogram after SDS treatment}

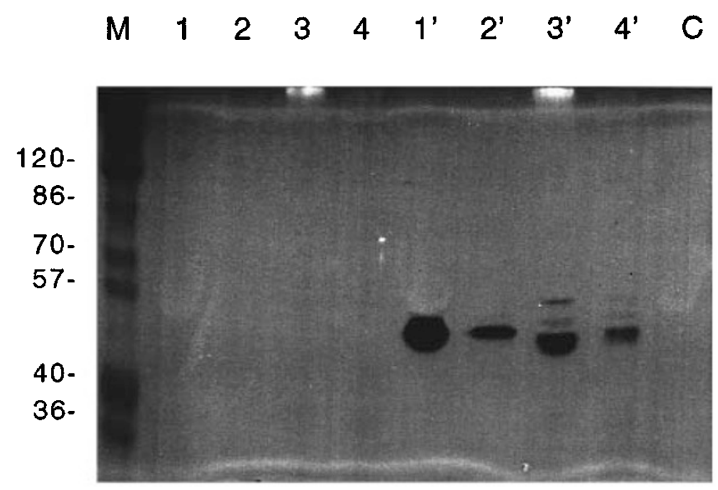

\section{C}

\section{coomassie blue stained zymogram}

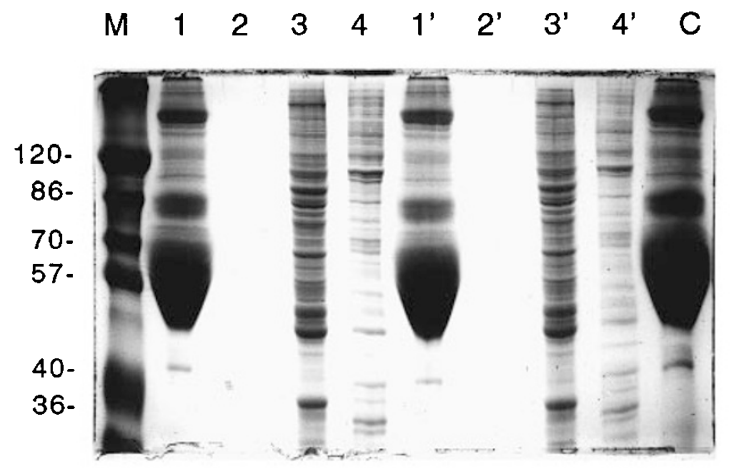

Figure 1 Detection of nuclease activities in various fractions of mycoplasmafree (lanes 1-4) or M. hyorhinis-infected (lanes $1^{\prime}-4^{\prime}$ ) cultures of PaTu 8902 cells. Ethidium bromide (A, B) and Coomassie blue stained zymogram (C) of culture supernatants (lanes 1, $1^{\prime}$ ), serum-free culture supernatants (lanes 2 , $2^{\prime}$ ), cell homogenates (lanes $3,3^{\prime}$ ), nuclear extracts (lanes $4,4^{\prime}$ ) and culture medium (C). $10 \mu \mathrm{l}$ supernatant or $60 \mu \mathrm{g}$ protein were applied for each lane. To identify 'false' positive bands in (A), the zymogram was soaked in $1 \%$ SDS for $4 \mathrm{~h}$ to remove DNA binding proteins and subsequently stained again with ethidium bromide (B). M: molecular mass markers in $\mathrm{kDa}$ as indicated 
fractions prepared from non-infected cells exhibited nuclease activities (Figure 1B, lanes 1-4). In contrast, all fractions of mycoplasma-infected cultures contained nuclease activities with molecular masses in the range of $47-54 \mathrm{kDa}$ (Figure 1B, lanes $1^{\prime}$ to $\left.4^{\prime}\right)$. Cell culture supernatants exhibited considerably higher nuclease activities than cell homogenates or nuclear extracts. For example, in the zymogram shown in Figure 1, we applied about 1/200 of the total culture supernatant and $1 / 50$ of the total cell homogenate from one culture dish (35 $\mathrm{mm}$ in diameter). The intensity of the nuclease activity bands differed between the various fractions. In the supernatant we detected three hardly separated bands of which the lowest $(47 \mathrm{kDa})$ exhibited the highest nuclease activity. Identical nuclease activities were also detected in serum-free supernatants. Cell homogenates and nuclear extracts contained three well separable nuclease bands; the $47 \mathrm{kDa}$ band again exhibited the highest nuclease activity. In contrast to DNase I, the mycoplasma nuclease activities were not reduced by addition of reducing agents like DTE or DTT. Figure $1 \mathrm{C}$ gives the zymogram gel after protein staining with Coomassie blue indicating that identical amounts of cellular and nuclear protein had been applied. Since the nuclease activity was not increased in nuclear extracts, we assume that the nucleases were not concentrated within the nuclei but transferred into this fraction during their isolation.

\section{Induction of apoptosis leads to an increase in nuclease activity in homogenates of mycoplasma- infected cells}

Inhibition of protein synthesis by cycloheximide is known to induce apoptosis in a number of cell systems (Martin et al, 1990; Martin, 1993). Using morphological criteria, we had found that this is also true for PaTu 8902 cells (Paddenberg et al, 1996). Therefore we employed cycloheximide treatment of PaTu 8902 cells to compare the amount of nuclease activity in cell homogenates of control and apoptotic cells. In these experiments attached and detached cells were analyzed separately (Figure 2). Zymogram analysis revealed that the homogenates of mycoplasma-free cultures were nuclease negative even after exposure to the apoptotic stimulus (Figure 2A). In contrast, cell homogenates of contaminated cultures exhibited nuclease activities (Figure 2B). Homogenates of detached cells from infected cultures showed a clear increase in the mycoplasmal nuclease activity after induction of apoptosis that correlated with the cycloheximide concentration employed. In contrast, the amount of mycoplasmal nuclease activity in the homogenates of attached cells was independent to the cycloheximide concentration or exhibited a weak increase.

\section{$\mathrm{Ca}^{2+} / \mathrm{Mg}^{2+}$-induced DNA ladder formation is restricted to nuclei isolated from mycoplasma- infected cells}

Isolated nuclei are often used to verify the presence or activation of apoptotic endonucleases. To this aim, nuclei are incubated in presence of calcium and magnesium with or without addition of cell homogenates. Subsequently the extracted DNA is examined by agarose gel electrophoresis for the formation of a DNA ladder which is considered to be indicative of the presence of endo- or exogenous $\mathrm{Ca}^{2+} / \mathrm{Mg}^{2+}$ dependent apoptotic endonuclease(s).

In similar experiments we compared nuclei isolated from infected and non-infected cells. In the presence of calcium and magnesium, the DNA of nuclei isolated from mycoplasma-infected cultures was cleaved into multiples of 200 base pairs. This DNA ladder formation was suppressed in EDTA containing buffer. In contrast, the
A -mycoplasma

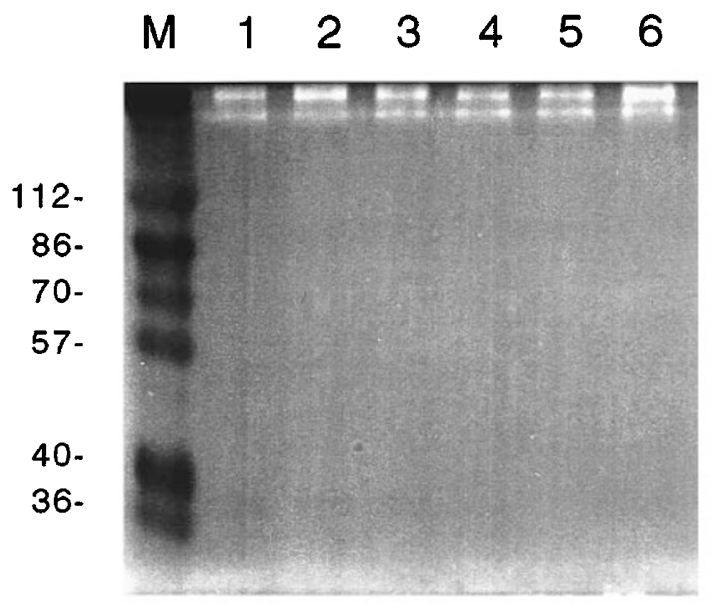

B +mycoplasma

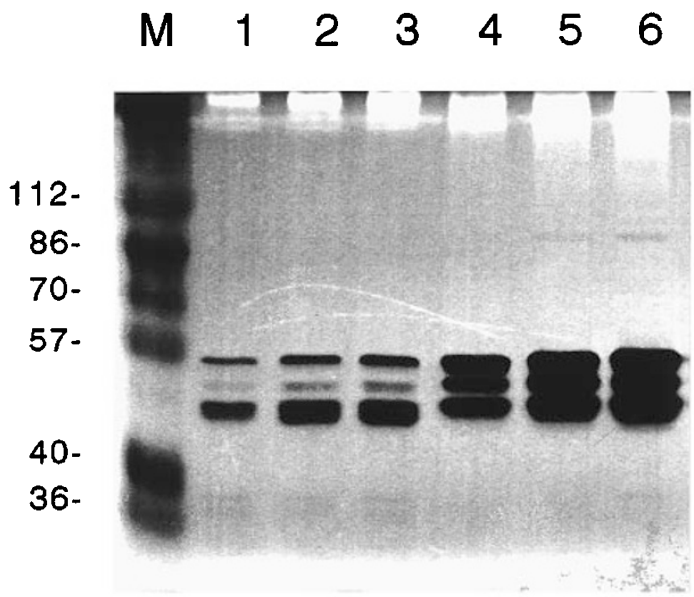

Figure 2 Zymogram of cell homogenates of cycloheximide treated $M$. hyorhinis-free (A) and -infected PaTu 8902 cells (B). Adherent (lanes 1-3) and detached (lanes 4-6) cells were handled separately. The cells were either untreated (lanes 1,4$)$ or exposed to $1 \mu \mathrm{g} / \mathrm{ml}($ lanes 2,5$)$ or $5 \mu \mathrm{g} / \mathrm{ml}($ lanes 3,6$) \mathrm{cycloheximide} \mathrm{for}$ $48 \mathrm{~h}$. Per lane $20 \mu \mathrm{g}$ cell homogenate were applied. M: molecular mass markers in $\mathrm{kDa}$ as indicated 
DNA of nuclei isolated from non-infected cells kept its high molecular weight organization under both conditions (Figure 3). The small amount of DNA detected in these cases was caused by the low solubility of undegraded DNA (the DNA formed unpipettable plugs which were not transferable into the gel pockets). However, addition of partially purified mycoplasma nucleases to these nuclei induced the formation of a DNA-ladder (Figure 3). These results

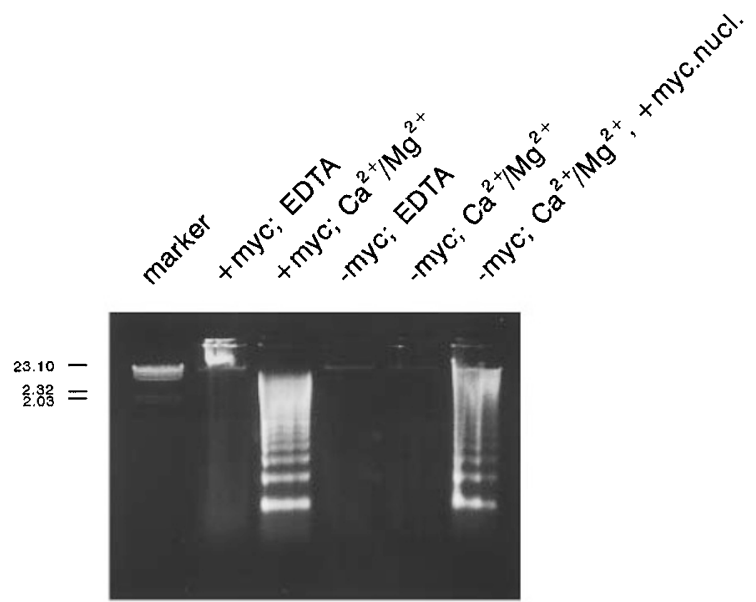

Figure 3 DNA degradation in nuclei isolated from M. hyorhinis-infected $(+\mathrm{myc})$ or -free PaTu 8902 cells $(-\mathrm{myc})$. Before DNA isolation the nuclei were incubated in buffer containing $2 \mathrm{mM}$ EDTA or $2 \mathrm{mM} \mathrm{CaCl} / 2 \mathrm{mM} \mathrm{MgCl} 2$ or $2 \mathrm{mM}$ $\mathrm{CaCl}_{2} / 2 \mathrm{mM} \mathrm{MgCl}_{2}$ plus partially purified mycoplasma nucleases. Molecular mass markers in kbp as indicated suggest that the mycoplasma nucleases present in the nuclear extracts of infected cells (Figure 1) were indeed responsible for the $\mathrm{Ca}^{2+} / \mathrm{Mg}^{2+}$-dependent DNA cleavage.

\section{Partial purification of mycoplasma nucleases}

As shown in Figure 1, supernatants of $M$. hyorhinis-infected cells contained high amounts of nuclease activities. These endonucleases were also present in supernatants of infected cells kept under serum-free conditions. Since serum deprivation is known to induce apoptosis in a number of cell systems, we analyzed the viability of the used PaTu 8902 cells cultured in the presence or absence of serum by using the MTT-test. This assay quantitates the conversion of the water soluble MTT into the insoluble purple formazan that is catalysed by mitochondrial dehydrogenases of living cells. Using this test, we detected no difference in viability of serum containing to deprived cultures $\left(\Delta O D_{570 ~ n m}\right.$ with serum: 2.8; without serum: 2.7). Microscopical analysis of serum deprived PaTu 8902 cultures revealed a reduction in the number of adherent cells by $10 \%$, but no obvious increase in the number of detached cells (data not shown) indicating that serum removal reduced the rate of proliferation, but did not induce apoptosis.

In order to reduce the contamination by unrelated proteins, serum-free supernatants were used as source for attempts to further purify these enzymes under native conditions. The best separation protocol found was cation exchange chromatography using a S Sepharose Fast Flow column (Figure 4A). Bound proteins were eluted with a linear
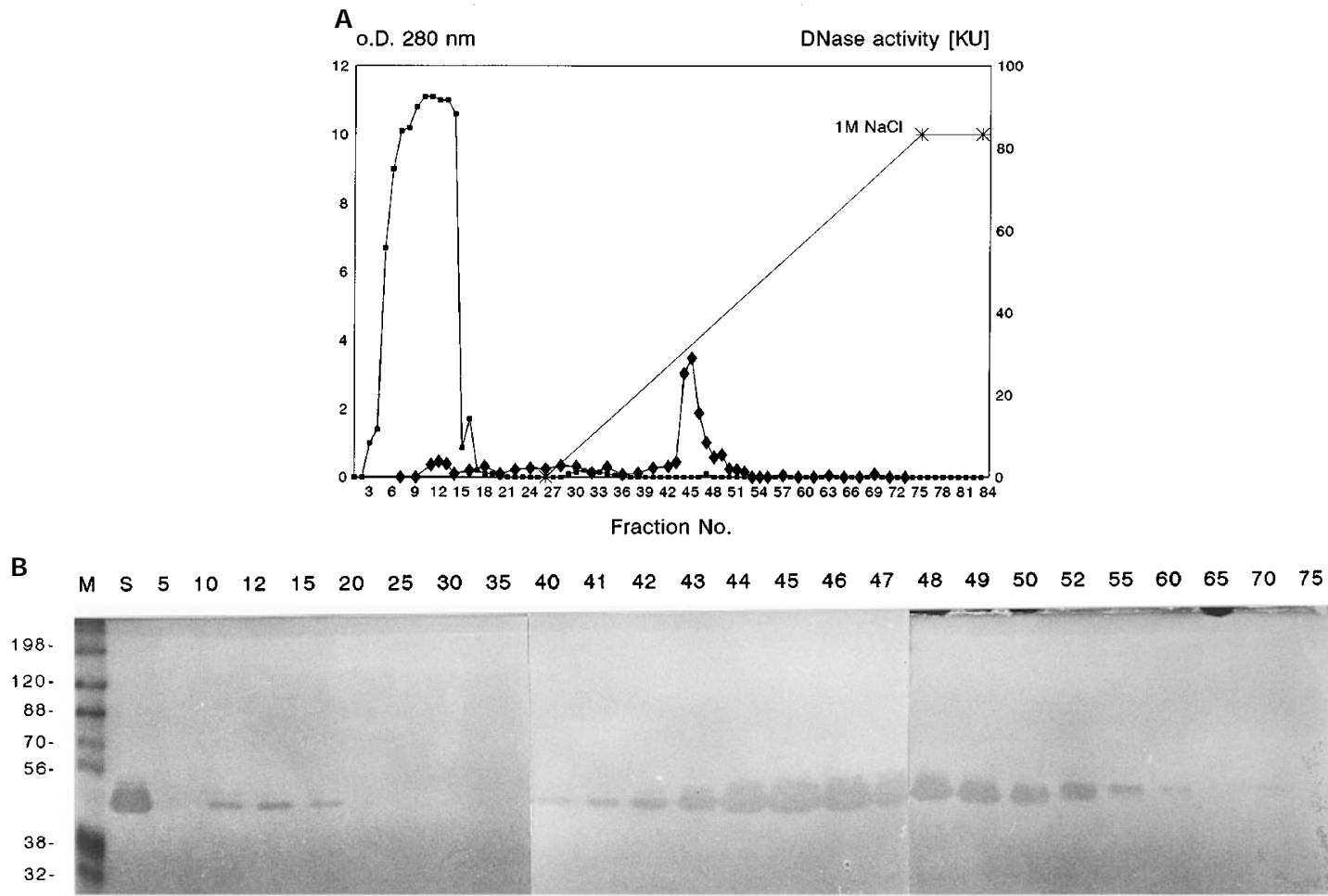

Figure 4 Partial purification of mycoplasma nucleases from serum-free PaTu 8902 culture supernatants. (A) Protein elution profile ( $\mathbf{\square})$ of a S Sepharose Fast Flow column and detection of nuclease activity $(\bullet)$ in the obtained fractions by the photometric assay, (B) corresponding zymogram analysis. Fraction numbers as indicated, S: serum-free culture supernatant, M: molecular mass markers in $\mathrm{kDa}$ as indicated 
gradient of $0-1 \mathrm{M} \mathrm{NaCl}$. The obtained fractions were screened for nuclease activity by the photometric assay (Figure 4A) as well as by the zymogram technique (Figure $4 \mathrm{~B})$. The nuclease activity eluted in a single peak at $350 \mathrm{mM}$ $\mathrm{NaCl}$. However, no clear separation of the three nuclease entities was achieved. Analysis of the fractions collected by SDS-PAGE followed by silver staining did not reveal any protein bands at all (not shown, see also Figure 1C).

\section{Internucleosomal DNA fragmentation in isolated nuclei by partially purified mycoplasma nucleases}

Nuclei isolated from MCF-7 cells were used as substrate to examine the time dependent DNA degradation catalysed by the partially purified mycoplasma endonucleases (Figure 5). Isolated nuclei were incubatd with mycoplasma nucleases in buffers containing $2 \mathrm{mM} \mathrm{CaCl}_{2}$ and $2 \mathrm{mM} \mathrm{MgCl} 2$ or $2 \mathrm{mM}$ EDTA. Control incubations were performed in the absence of nucleases. Under all conditions the DNA was intact at time zero; it formed highly viscous plugs and was not transferable into the gel pockets. After $1 \mathrm{~h}$ of incubation at $37^{\circ} \mathrm{C}$ in the presence of mycoplasma nucleases as well as $\mathrm{Ca}^{2+}$ and $\mathrm{Mg}^{2+}$-ions, most of the DNA was degraded into high molecular weight fragments and a small fraction into multiples of $200 \mathrm{bp}$. DNA-ladder formation was more apparent after $3 \mathrm{~h}$. After $24 \mathrm{~h}$ of incubation, the DNA was completely hydrolysed into oligonucleosomal fragments. Incubations in the presence of EDTA resulted in no detectable DNA-degradation (Figure 5) indicating that the mycoplasma endonucleases are $\mathrm{Ca}^{2+}$ / $\mathrm{Mg}^{2+}$-dependent enzymes. Control incubations in the presence of $\mathrm{Ca}^{2+}$ and $\mathrm{Mg}^{2+}$-ions, but in absence of mycoplasma nucleases resulted in the degradation of negligible amounts of DNA into high molecular weight fragments detected as smear or faints bands just underneath the gel pockets demonstrating that the isolated nuclei contained an endogenous nuclease activity only able to form large DNA-fragments (Figure 5).

Interestingly, incubation of isolated nuclei under identical conditions with increasing amounts of bovine pancreatic DNase I resulted in the formation of high molecular mass fragments at low and small fragments at high DNase I concentration after an overnight incubation at room temperature (Figure 6).

\section{Mycoplasma nucleases induce morphological nuclear changes comparable to those described for apoptotic cells}

In order to investigate whether the internucleosomal DNA cleavage by mycoplasmal endonucleases was accompanied by apoptotic morphological changes, isolated nuclei were incubated with enriched mycoplasma nucleases, stained with the DNA binding fluorescence dye Sytox and subsequently analyzed by confocal laserscan microscopy. The data obtained demonstrate that incubation of nuclei isolated from PaTu 8902 cells resulted in morphological changes comparable to those observed in apoptotic cells: The nuclei shrunk, the DNA condensed and formed plaques at the inner nuclear membrane (Figure 7B). In contrast, control nuclei incubated without nucleases exhibited a homogenous DNA staining (Figure 7A).

\section{Ionic requirements of mycoplasma nucleases}

Photometric analysis using double stranded native calf thymus DNA as substrate allowed quantitative estimations of the nuclease activity. Therefore this method was employed for the further characterization of the ionic requirements of the enriched mycoplasmal endonucleases. We found that neither calcium nor magnesium alone were sufficient to induce DNA degradation (Figure 8A). Nuclease activity, i.e., DNA degradation was only seen in the presence of both ions. Maximal activity was obtained at an equimolar ratio of these ions or in the presence of an excess of magnesium over calcium ions, whereas an excess of calcium resulted in reduced activity. In the presence of calcium, magnesium could partially be replaced by manganese (Figure $8 \mathrm{~B}$ ); then only about $30 \%$ of the maximal activity was obtained. Under both conditions $\left(\mathrm{CaCl}_{2}+\mathrm{MgCl}_{2}\right.$ or $\left.\mathrm{CaCl}_{2}+\mathrm{MnCl}_{2}\right)$, the DNA was cleaved at internucleosomal sites (Figure 5 and not shown).

However, compared to physiological conditions the ionic concentrations used in these experiments represent extreme points or even exceed them: The average concentrations of both calcium and magnesium in the extracellular space amount to 1-2 mM, whereas inside the cell their concentrations are in the range of $0.1 \mu \mathrm{M}$ for $\mathrm{Ca}^{2+}$ - and 0.5-1 $\mathrm{mM}$ for $\mathrm{Mg}^{2+}$-ions. Therefore we investigated the mycoplasma nuclease activity at more physiological ionic conditions, i.e., in the presence of $1 \mathrm{mM}$ $\mathrm{MgCl}_{2}$ combined with $\mathrm{CaCl}_{2}$-concentrations ranging from $0.1 \mu \mathrm{M}$ to $1 \mathrm{mM}$. As shown in Figure $8 \mathrm{C}$, clear DNA degradation occurred only under extracellular ionic conditions of 0.1 to $1 \mathrm{mM} \mathrm{CaCl} 2$. This indicates that internucleosomal DNA degradation by mycoplasma nucleases required an extreme increase of the intracellular calcium concentration either by release from intracellular stores and/or a shift from the extracellular space.

Several $\mathrm{Ca}^{2+} / \mathrm{Mg}^{2+}$-dependent and other endonucleases are characterized by an inhibition by $\mathrm{ZnCl}_{2}$ (Gaido and Cidlowski, 1991; Peitsch et al, 1993). This is also true for the mycoplasma nucleases: In the presence of $10 \mu \mathrm{M}$ $\mathrm{ZnCl}_{2}$, the activity was reduced to about $10 \%$ of control (Figure 8D). As expected, the $\mathrm{Ca}^{2+} / \mathrm{Mg}^{2+}$-stimulated nuclease activity was also inhibited by $100 \mu \mathrm{M}$ EGTA or EDTA (not shown).

\section{$\mathrm{pH}$ dependence of the mycoplasma nucleases}

A number of different candidate endonucleases responsible for the apoptotic DNA degradation have been proposed: (i) Enzymes which develop their maximal activity at acidic $\mathrm{pH}$ like DNase II (Barry and Eastman, 1993; Gottlieb et al, 1996) or nuc-1 of Caenorhabditis elegans (Hevelone and Hartman, 1988) and (ii) enzymes which need neutral or weakly basic conditions for activation like the $\mathrm{Mg}^{2+}$-dependent endonuclease detected in various myeloid cell lines (Kawabata et al, 1993), DNase $\delta$ of rat thymocytes (Shiokawa et al, 1994), NUC18 (Gaido and Cidlowski, 1991) or DNase I (Peitsch et al, 1993).

As estimated by the photometric assay using double stranded native DNA as substrate, the mycoplasma 
nucleases exhibited their highest DNA degrading activity at $\mathrm{pH} 7.8$ to 8.0 and about half maximal activity was obtained at $\mathrm{pH} 6.0$ and $\mathrm{pH} 9.0$ (Figure 9). Comparable data have been described for endonucleases detected in extracts of the mycoplasma species $M$. arthritidis, $M$. pneumoniae and Acholeplasma laidlawii (Pollack and Hoffmann, 1982).

\section{Two dimensional zymogram analysis of partially purified mycoplasma nucleases}

Isoelectric focusing in a $\mathrm{pH}$ gradient of 3-10 followed by separation in a DNA containing $12 \%$ SDS-polyacrylamide gel was used to estimate the isoelectric point (IP) of the
$0 \mathrm{~min}$.

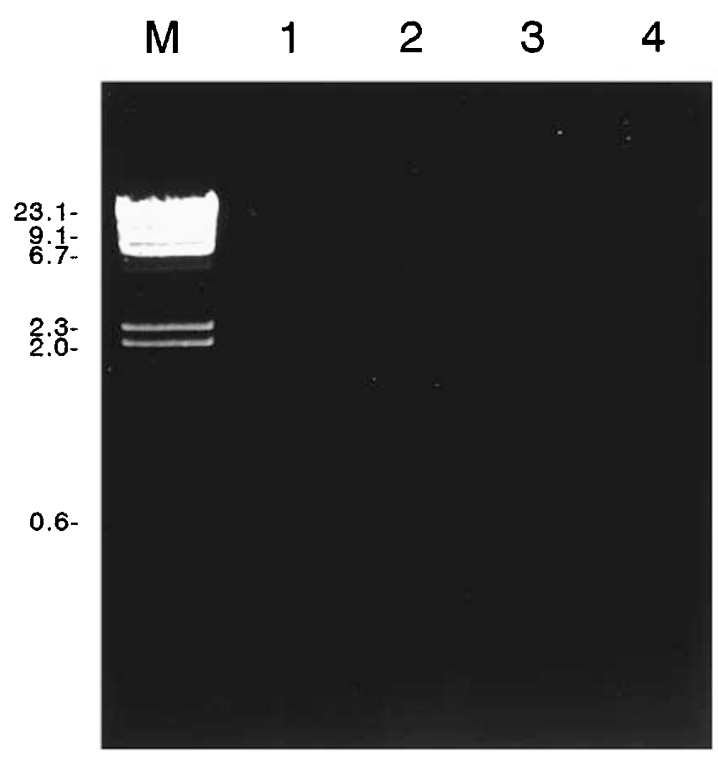

$3 \mathrm{~h}$

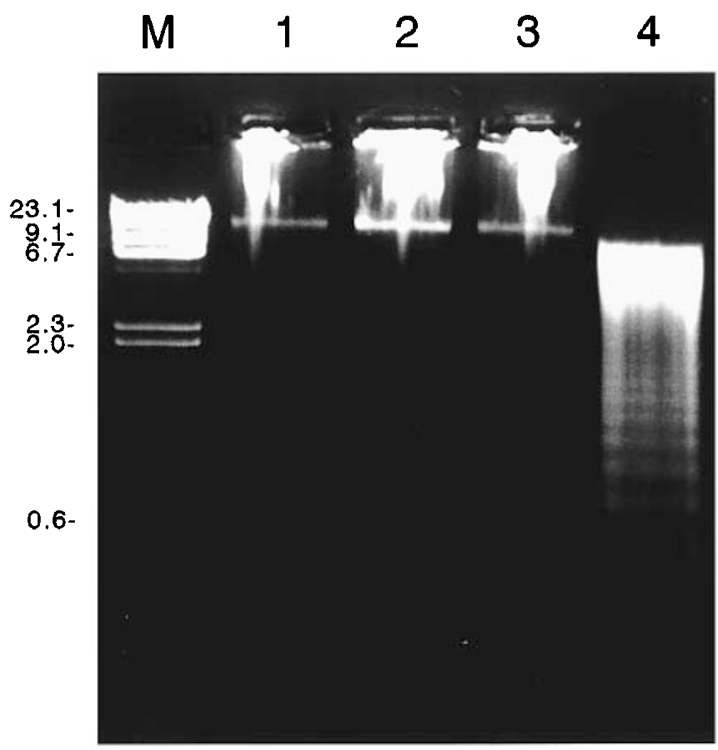

$1 \mathrm{~h}$

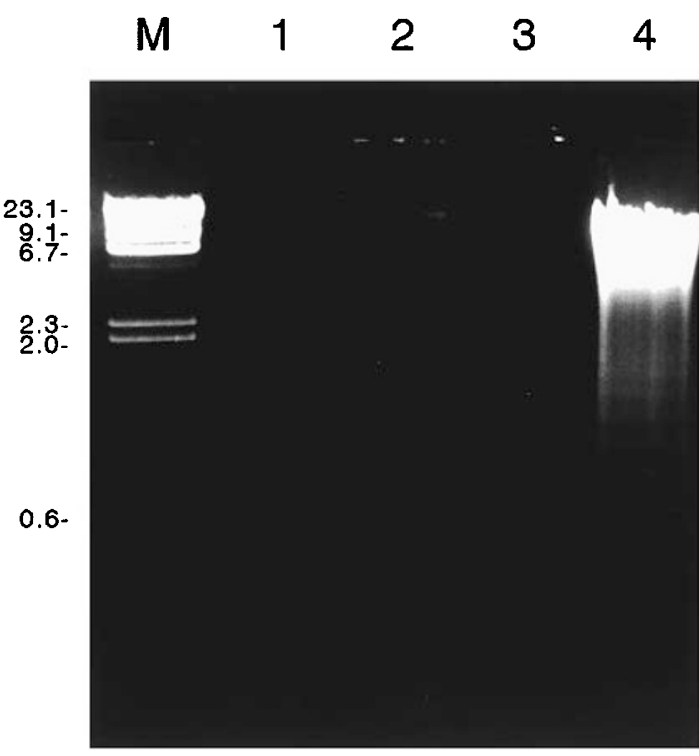

$24 \mathrm{~h}$

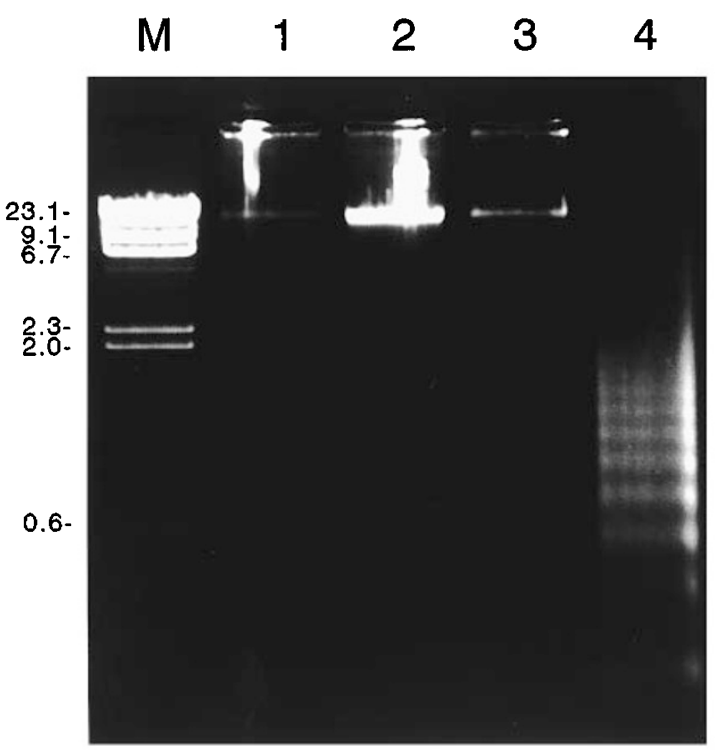

Figure 5 Time dependent progression of DNA degradation in isolated MCF-7 nuclei by partially purified mycoplasma nucleases. MCF-7 nuclei were incubated in the presence of $2 \mathrm{mM}$ EDTA (lane 1), $2 \mathrm{mM} \mathrm{CaCl}_{2} / 2 \mathrm{mM} \mathrm{MgCl}_{2}$ (lane 2), $2 \mathrm{mM} \mathrm{EDTA}+5 \mu$ l partially purified mycoplasma nucleases (lane 3 ) or $2 \mathrm{mM} \mathrm{CaCl} / 2 \mathrm{mM}$ $\mathrm{MgCl}_{2}+5 \mu \mathrm{l}$ partially purified mycoplasma nucleases (lane 4). Incubation times at $37^{\circ} \mathrm{C}$ were as indicated. Molecular mass markers in kbp as indicated 
mycoplasma nucleases. As shown in Figure 10, the partially purified mycoplasma nucleases migrated in at least three spots with IPs between 8.1 and 9.5. Therefore they differed distinctly from bovine pancreatic DNase I whose isoenzymes exhibit IPs in the range of 3.5-4.0 (Yasuda et al, 1989). Up to

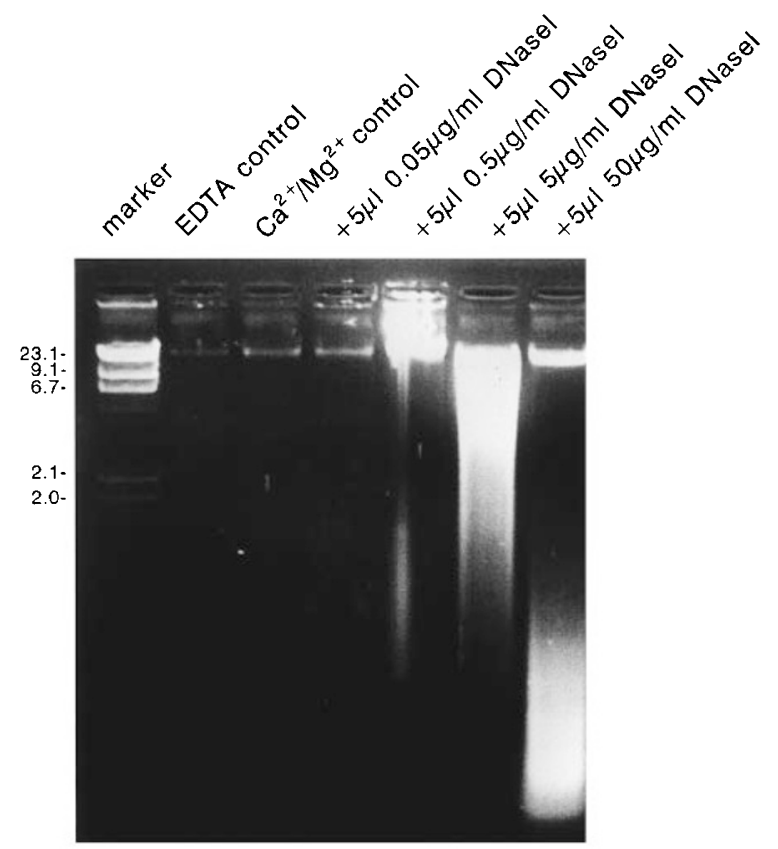

Figure 6 DNA degradation in isolated MCF-7 nuclei by bovine pancreatic DNase I. Nuclei were incubated in presence of $2 \mathrm{mM} \mathrm{CaCl} / 2 \mathrm{mM} \mathrm{MgCl}_{2}$ and increasing concentrations of DNase I. Control incubations were performed in the absence of nuclease in buffers containing either $2 \mathrm{mM}$ EDTA or $2 \mathrm{mM}$ $\mathrm{CaCl}_{2} / 2 \mathrm{mM} \mathrm{MgCl}_{2}$. Molecular mass markers in $\mathrm{kbp}$ as indicated now we do not know whether the nucleases of different molecular mass were caused by different proteins or by modifications of only one protein. Since the mycoplasma nucleases are of bacterial origin, differences in the glycosylation pattern can be excluded.

\section{Influence of actin-gelsolin segment I complexes on nuclease activity}

The inhibition by G-actin is a property specific for DNase I (Lazarides and Lindberg, 1974; Mannherz et al, 1975). Therefore, we compared the effect of this protein on the activity of bovine pancreatic DNase I and the mycoplasma nucleases. Since the mycoplasma nucleases were eluted from the S Sepharose Fast Flow column in a buffer containing $350 \mathrm{mM} \mathrm{NaCl}$ and since G-actin polymerizes in presence of high salt, we employed for these experiments the 1:1 complex of G-actin and gelsolin segment 1 . Within this complex actin is stabilized in its G-form without loss of its DNase I inhibitory capacity.

As shown in Figure 11, the endonucleolytic activity of DNase I was drastically reduced in the presence of $70 \mu \mathrm{M}$ actin-gelsolin segment 1 , i.e., at a molar ratio of DNase I and the complex of $1: 23$. Although the employed amount of mycoplasma nuclease activity was only about $1 / 7$ of that of DNase I as tested by the photometric assay, no inhibitory effect by the actin-segment 1 complex was obtained under otherwise identical conditions.

\section{Discussion}

Apoptotic cell death is characterized by morphological changes like cell and nuclear shrinkage and fragmentation as well as by biochemical alterations like the degradation of the DNA into multiples of 200 base pairs. However, it has
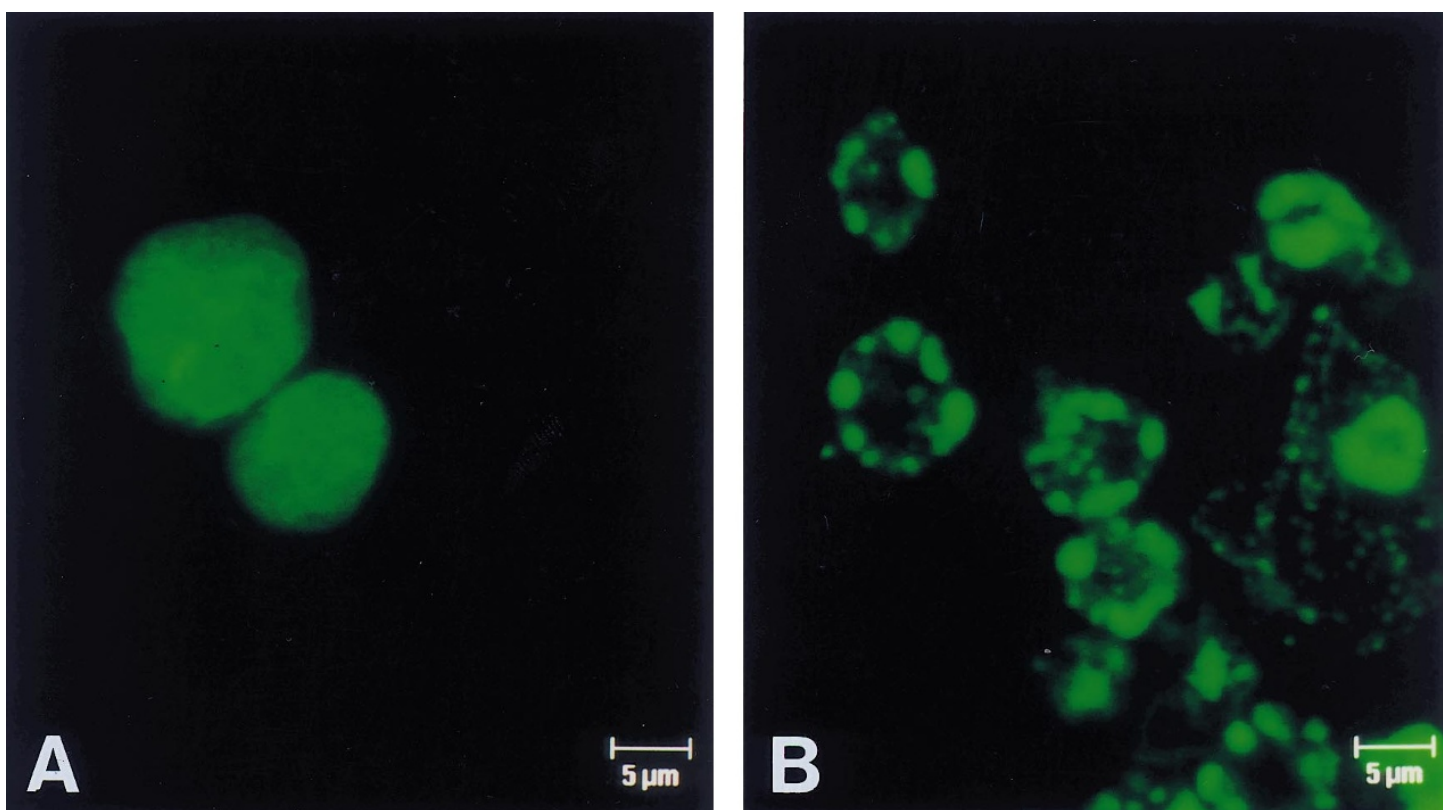

Figure 7 Sytox staining of isolated PaTu 8902 nuclei incubated either in $\mathrm{Ca}^{2+} / \mathrm{Mg}^{2+}$ buffer $(\mathbf{A})$ or in buffer supplemented with partially purified mycoplasma nucleases (B) for $20 \mathrm{~h}$ at room temperature 
Dependence of mycoplasma nuclease activity on calcium and magnesium

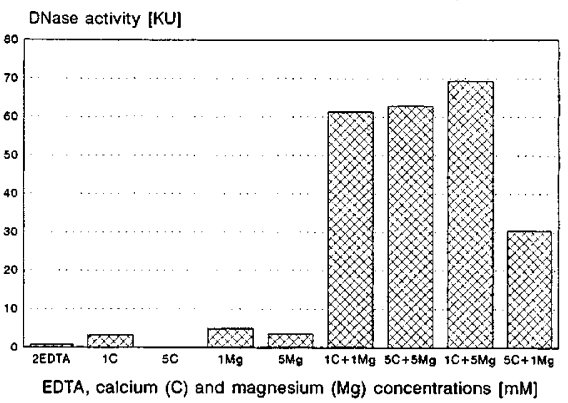

A
Calcium dependence of mycoplasma nucleases

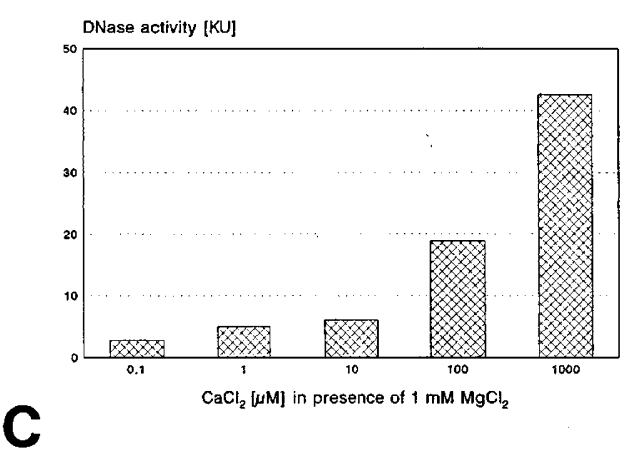

Comparison of the influence of magnesium and manganese on nuclease activity

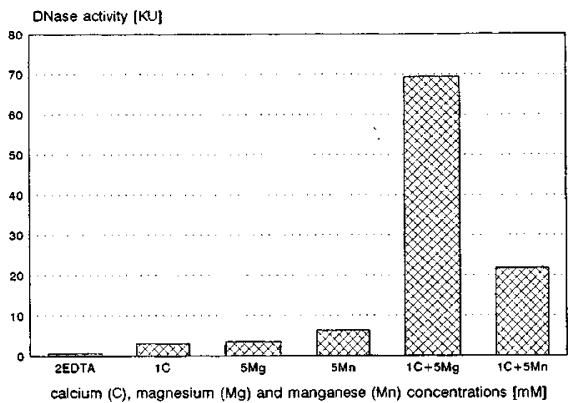

B

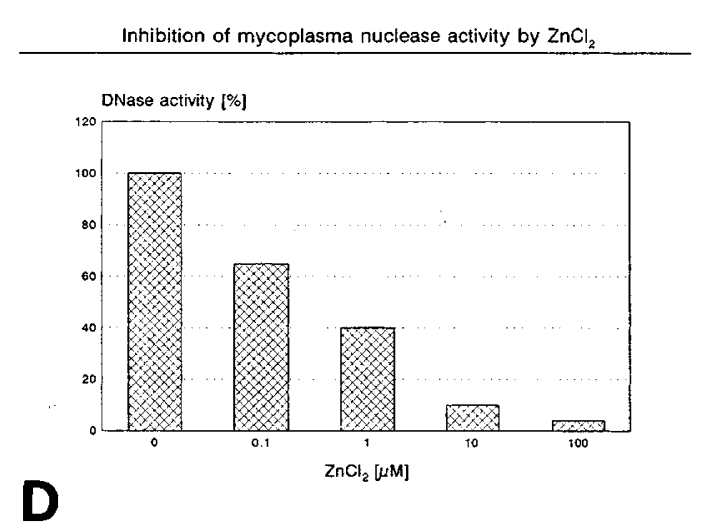

D

Figure 8 lonic requirements of the mycoplasma nucleases as estimated by the photometric assay using double stranded native calf thymus DNA as substrate. (A) Dependence on calcium and magnesium. (B) Comparison of the influence of magnesium and manganese. (C) Determination of the calcium dependence. (D) Inhibition by zinc chlorid. In the last series, measurements were performed in the presence of $1 \mathrm{mM} \mathrm{CaCl}_{2}$ and $1 \mathrm{mM} \mathrm{MgCl}_{2}(=100 \% \mathrm{DNase}$ activity)

repeatedly been shown that the morphological alterations are not necessarily accompanied by internucleosomal DNA fragmentation. For instance, apoptosis of cultured fibrosarcoma cells induced in serum-free medium is not paralleled by internucleosomal DNA fragmentation (Watanabe et al, 1995). Etoposide treatment of the human, androgen-independent prostatic carcinoma cell line DU-145 induces morphological features of apoptosis, but the DNA is only cleaved into $50 \mathrm{kbp}$ units (Oberhammer et al, 1993). Exposure of MCF-7 cells to the anti-estrogen tamoxifen induces apoptosis morphologically but no DNA degradation into oligonucleosomes (Otto et al, 1996). Based on our experiments with various cell culture systems we propose that in at least a large number of established cell lines induction of apoptosis does not result in internucleosomal DNA degradation, unless the cells are infected with mycoplasmas. Cleavage of the DNA at internucleosomal sites seems to be restricted mainly to cells of primary cultures or in vivo systems. In the past, this fact may have been overlooked because it was obscured by DNA cleavage into multiples of $200 \mathrm{bp}$ most probably caused by endonucleases expressed by contaminating mycoplasmas (Paddenberg et al, 1996).

That mycoplasma contamination of eukaryotic cell cultures may be the rule and not the exception, verify contamination rates of about $85 \%$ which were reported

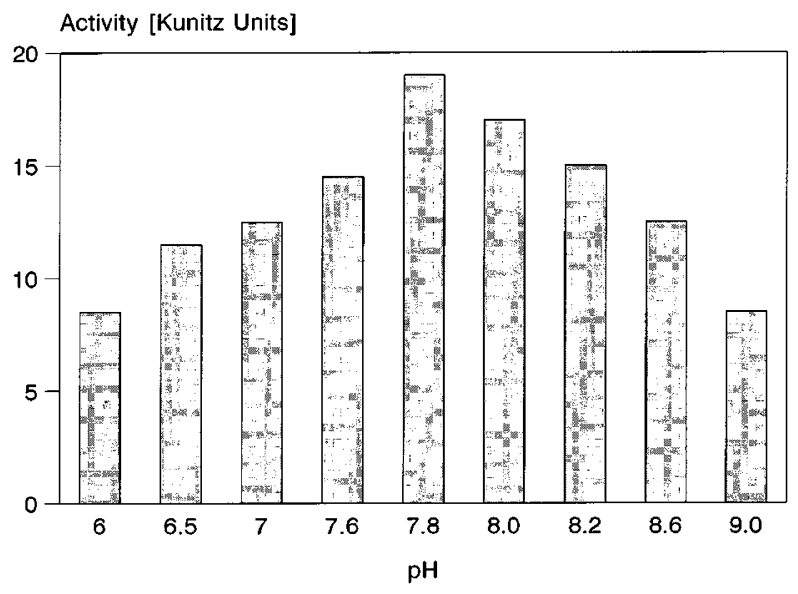

Figure 9 Photometric determination of the $\mathrm{pH}$ dependence of the activity of the mycoplasma nucleases. As substrate native, double stranded calf thymus DNA was employed

when using highly sensitive techniques like PCR (Rottem and Barile, 1993; Rawadi and Dussurget, 1995). Five mycoplasma species, namely $M$. hyorhinis, $M$. orale, $M$. arginini, M. fermentans and Acholeplasma laidlawii, 


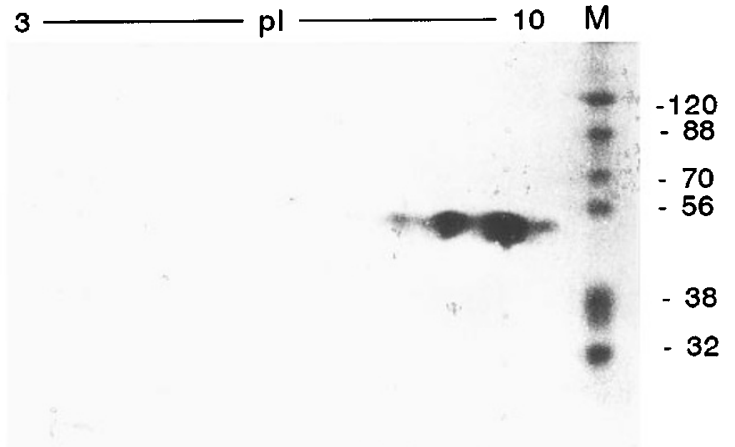

Figure 10 Two-dimensional zymogram analysis of partially purified mycoplasma nucleases. M: molecular mass markers in $\mathrm{kDa}$ as indicated

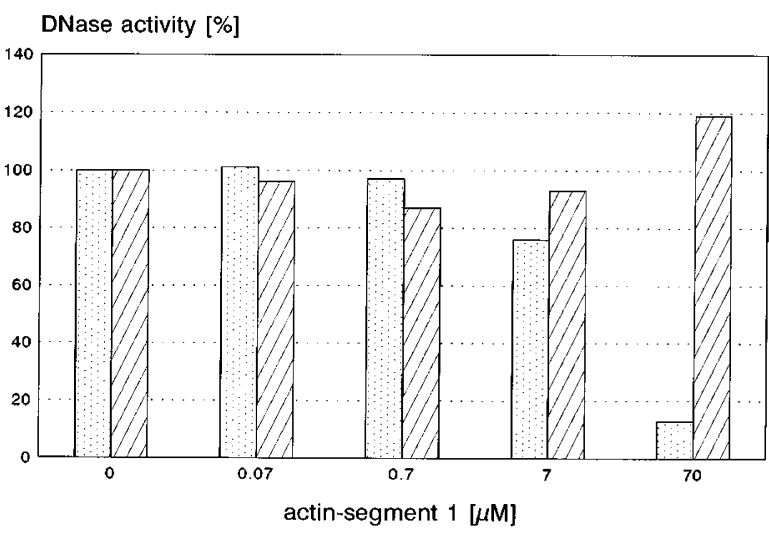

Figure 11 Influence of the actin-gelsolin segment 1 complex on the activity of DNase I and mycoplasma nucleases. Measurements were performed in the presence of $1 \mathrm{mM} \mathrm{CaCl}, 1 \mathrm{mM} \mathrm{MgCl}_{2}$ and concentrations of actin-segment 1 complex as indicated. Dotted columns: bovine pancreatic DNase I (100 ng/ml); striped columns: enriched mycoplasma nucleases

account for more than $95 \%$ of the isolates (McGarrity et al, 1992). Analysis of the nucleases of various mycoplasma species by the zymogram technique revealed that the most consistent feature is a set of nuclease activities in the 35$70 \mathrm{kDa}$ range (Minion et al, 1993). The species expressing this pattern includes $M$. hyorhinis and $M$. fermentants. An exception represents the species Acholeplasma laidlawii which is characterized by nucleases with molecular masses of about $100 \mathrm{kDa}$.

The molecular masses of the nucleases which were detectable in supernatants, cell homogenates and nuclear extracts of $M$. hyorhinis-infected PaTu 8902 cells were in the range of $47-54 \mathrm{kDa}$. As we have shown recently, the expression of these nucleases was suppressed in the presence of chloramphenicol, an inhibitor of prokaryotic protein synthesis (Paddenberg et al, 1996). Under 'normal' conditions, the mycoplasma nucleases were harmless for the host cells. After cellular stress like inhibition of eukaryotic protein synthesis or treatment with the microtubule-depolymerizing drug vinblastin, they apparently enter the cell and cleave the chromatin into oligonucleosomal sized fragments (Paddenberg et al, 1996). This exactly mimics the situation of a cell system in which induction of apoptosis is accompanied by DNA fragmentation catalyzed by endogenous nucleases. Furthermore, homogenates of detached cells of infected cultures under stress exhibited increased levels of nuclease activities compared to those of untreated cells. We assume that this increase resulted from either an increased stickiness of mycoplasmas to damaged cells and/or an increased plasma membrane permeability for mycoplasmas or their nucleases. As long as mycoplasma contaminations are not taken into consideration, such results will erroneously be interpretated as an upregulation of endogenous apoptotic nucleases.

To our knowledge, there exist no investigations about the distribution of mycoplasma nucleases in eukaryotic cell systems. Using 'pure' prokaryotic cultures, Tyron and Baseman (1992) have shown that mycoplasmas growing on DNA containing agar plates produce clear zones around the colonies indicating that nuclease activities were soluble and secreted. On the other hand, Minion et al (1993) found in localization studies that the majority of the nucleases was associated with the bacteria. For example, the species M. pulmonis contains an external, membrane-bound nuclease activity, which constitutes approximately $20 \%$ of its total DNase activity (Minion and Goguen, 1986). The species $M$. penetrans exhibits two forms of nuclease activity: a $50 \mathrm{kDa}$ enzyme which was suggested to be an integral membrane protein, and a $40 \mathrm{kDa}$ nuclease as peripherial membrane protein which could easily be liberated by washing the cells with isotonic buffer (Bendjennat et al, 1997). In eukaryotic cultures, $M$. hyorhinis grow like most mycoplasma species as surface parasites strongly attached to the host cell membrane (Razin and Jacobs, 1992). Based on our data indicating different quantitative distributions of the three mycoplasma nucleases in cell homogenates and supernatants of eukaryotic cultures, we assume that the lower band dominating in the supernatant is a secreted variant, whereas the upper and middle bands of the nuclease triplet represent bacterial-associated or 'intrabacterially' located forms.

Nuclease activities were also detected in nuclear extracts of mycoplasma positive cells. However, the specific nucleolytic activity of the nuclear extracts was comparable or even lower to that of cell homogenates. It was not increased in nuclear extracts as one would expect in case of a specific nuclear localization of the enzymes. We therefore suspect that the endonucleases present in nuclear extracts are due to either nucleases contamination by the culture supernatants or originated from mycoplasmas attached to plasma membranes of the host cells. Indeed, only the nuclei isolated from infected cells exhibited internucleosomal DNA cleavage after incubation with $\mathrm{Ca}^{2+}$ and $\mathrm{Mg}^{2+}$-ions. Therefore the use of nuclear extracts as source for the isolation and/or characterization of apoptotic nucleases as it has been reported by Ucker et al (1992), Deng and Podack (1995), Sokolova et al (1995) or Zhang et al (1995) does not exclude the possibility of a contamination with mycoplasma nucleases.

The biochemical characterization of nucleases partially purified from serum-free supernatants of mycoplasma- 
infected cultures revealed, that the prokaryotic enzymes possess many characteristics similar to the eukaryotic apoptotic enonuclease(s) like a neutral to weakly basic $\mathrm{pH}$ optimum and the requirement of both $\mathrm{Ca}^{2+}$ and $\mathrm{Mg}^{2+}$ ions in the $\mathrm{mM}$ range for full activity. Furthermore, the mycoplasmal endonucleases were inhibited in presence of $\mathrm{Zn}^{2+}$-ions, EGTA and EDTA. Indeed, another mycoplasmal endonuclease, the $40 \mathrm{kDa}$ nuclease purified from $M$. penetrans, possesses an activity profile which is very similar to that of the $M$. hyorhinis nucleases: It is able to induce internucleosomal DNA cleavage in isolated substrate nuclei and its activity depends on both $\mathrm{Ca}^{2+}$ and $\mathrm{Mg}^{2+}$, it is inhibited by $\mathrm{Zn}^{2+}$, EGTA and EDTA, but not by reducing agents, and it has a $\mathrm{pH}$ optimum between $\mathrm{pH} 7$ and 8 (Bendjennat et al, 1997).

In contrast to the mycoplasma nucleases, purified DNase I was not able to cleave the DNA of substrate nuclei at internucleosomal sites. DNase I requires yet unknown factors contained for example in the nuclear extract of RG-17 cells or serum (Peitsch et al, 1993) to catalyse DNA ladder formation in isolated nuclei. In contrast to the mycoplasma nucleases, DNase I is inhibited by monomeric actin (Lazarides and Lindberg, 1974; Mannherz et al, 1975). Indeed, inhibition by monomeric actin has been demonstrated for the endonuclease constitutively present in nuclear extracts of thymocytes (Peitsch et al, 1993) and in rat prostatic homogenates (Rauch et al, 1997).

In summary, our data clearly demonstrate that investigations on apoptotic nucleases in cell culture systems can be dramatically falsified by mycoplasma contaminations. Therefore one has to doubt, whether all apoptotic nucleases described so far in established cell lines were indeed of eukaryotic origin. It will also be necessary to scrutinize experiments claiming induction or inhibition of apoptosis when solely based on DNA-ladder formation. In future experiments using established cell lines, it will be obligatory to exclude mycoplasmal infections by using for instance zymogram techniques to analyze cell culture supernatants of unstimulated cells for the presence of endonucleases and/or to check their expression after treatment with inhibitors of prokaryotic protein synthesis. In addition, it will be important to demonstrate that nucleases identified in cell culture systems also occur in mammalian tissues.

\section{Materials and Methods}

\section{Materials}

All reagents were of analytical grade and obtained from Sigma (Deisenhofen, Germany) unless otherwise stated.

\section{Cell culture}

The breast cancer cell line MCF-7 was maintained in phenolred-free DMEM (Dulbecco's modified Eagle Medium) supplemented with $10 \%$ fetal calf serum. The human pancreatic adenocarcinoma cell line PaTu 8902 was cultured in DMEM, $5 \%$ aseptical calf serum, $5 \%$ horse serum (Gibco, Eggenstein, Germany). In order to obtain serum-free supernatants, confluent cultures were washed twice with and switched to serum-free DMEM for 2 days.

\section{MTT assay}

The percentage of viable cells was determined using the MTT assay. In this colorimetric procedure, MTT (3-(4,5dimethylthiazol-2yl)-2,5diphenyltetrazolium bromide) is reduced by intracellular dehydrogenases of viable cells. MTT was added to PaTu 8902 cells (cultured on TC dishes, $35 \mathrm{~mm}$ in diameter) to a final concentration $0.5 \mathrm{mg} / \mathrm{ml}$ and incubated for $3 \mathrm{~h}$ at $37^{\circ} \mathrm{C}$. After removing the culture medium the converted dye was solubilized in $500 \mu$ lisopropanol. Lipids originating from cellular membranes, which may cause a turbididy increase of the solution, were removed by centrifugation $(17530 \mathrm{~g}, 20 \mathrm{~min})$. Finally, the O.D. was measured at $570 \mathrm{~nm}$.

\section{Isolation of nuclei}

Nuclei were isolated either from PaTu 8902 or MCF-7 cells. Nuclei isolated from both cell lines gave comparable results in DNA fragmentation assays and morphological studies. Since the preparation of nuclei from MCF-7 cells resulted in higher yield and purity (separation from cytoplasmic remnants), this cell line was preferentially employed for nuclei isolation.

Isolation of nuclei was performed as described by Almendral et al (1988). Trypsinized cells of a confluent $75 \mathrm{~cm}^{2}$ bottle were washed with PBS, centrifuged and resuspended in $1 \mathrm{ml}$ lysis buffer $(10 \mathrm{mM}$ Tris- $\mathrm{HCl}, \mathrm{pH} 7.6,10 \mathrm{mM} \mathrm{NaCl}, 3 \mathrm{mM} \mathrm{MgCl} 2,0.5 \%$ Nonidet P-40). After incubation on ice for $5 \mathrm{~min}$ the cells were disrupted by 10 strokes with a glass/teflon homogenizer. Cell debris and nuclei were separated by density gradient centrifugation using $4 \mathrm{ml}$ of $15 \mathrm{mM}$ Tris- $\mathrm{HCl}, \mathrm{pH} 7.6$, $0.7 \mathrm{M}$ sucrose, $60 \mathrm{mM} \mathrm{KCl}, 15 \mathrm{mM} \mathrm{NaCl}, 0.5 \mathrm{mM}$ spermidine, $0.15 \mathrm{mM}$ spermine, $2 \mathrm{mM}$ EDTA, $0.5 \mathrm{mM}$ EGTA (ethylene glycolbis( $\beta$-aminoethyl ether) $\mathrm{N}, \mathrm{N}, \mathrm{N}, \mathrm{N}^{\prime}$-tetraacetic acid), $0.65 \mathrm{mM}$ DTE (dithioerythritol), $0.1 \%$ Triton-X-100. The obtained nuclei were resuspended to a concentration of $2-4 \times 10^{7}$ nuclei $/ \mathrm{ml}$ in $50 \mathrm{mM}$ Tris- $\mathrm{HCl}, \mathrm{pH} 7.6,5 \mathrm{mM} \mathrm{KCl}, 0.1 \mathrm{mM}$ EDTA and stored on ice. For longer storage at $-20^{\circ} \mathrm{C}$, they were additionally mixed with one volume glycerol.

\section{Cell homogenates and nuclear extracts}

Floating or trypsinized cells were pelleted by centrifugation, washed with PBS and resuspended in homogenisation buffer $(10 \mathrm{mM}$ Tris- $\mathrm{HCl}$, pH 8.0, 5 mM 1-O-octyl- $\beta$-glucopyranosid, 0.5 mM PMSF [phenylmethylsulfonyl fluoride], $1 \mathrm{mM}$ EDTA). Subsequently the cells were broken up by three cycles of freezing and thawing.

$10^{7}$ nuclei were pelleted by centrifugation and resuspended in $20 \mu \mathrm{l} 20 \mathrm{mM}$ HEPES, pH 7.9, 25\% glycerol, $600 \mathrm{mM} \mathrm{KCl}, 1.5 \mathrm{mM}$ $\mathrm{MgCl}_{2}, 0.2 \mathrm{mM}$ EDTA, $0.5 \mathrm{mM}$ DTT (dithiothreitol), $0.5 \mathrm{mM}$ PMSF. Then the nuclei were incubated for $60 \mathrm{~min}$ on ice and occasionally thoroughly mixed on a vortex mixer. Solubilized nuclear proteins and DNA were separated by centrifugation $(10 \mathrm{~min}, 12,000 \times g)$. Protein concentration was measured as described by Bradford (1976).

\section{DNA staining of isolated nuclei with SYTOX ${ }^{\mathrm{TM}}$ Green nucleic acid stain (S-7020)}

$2 \times 10^{5}$ nuclei were diluted in two volumes $10 \mathrm{mM}$ HEPES $\mathrm{pH} 7.0$, $40 \mathrm{mM} \beta$-glycerophosphate, $50 \mathrm{mM} \mathrm{NaCl}, 3 \mathrm{mM} \mathrm{CaCl} 2$ and $3 \mathrm{mM}$ $\mathrm{MgCl}_{2}$. After addition of $5 \mu \mathrm{l} 20 \mathrm{mM}$ Tris-acetate, $\mathrm{pH} 7.8$ (control) or $5 \mu \mathrm{l}$ enriched mycoplasma nucleases, the mixtures were incubated 
overnight at room temperature (RT). For fixation $20 \%$ formaldehyde was added to a final concentration of $2 \%$. After 20 min the nuclei were applied to coverslips and allowed to dry for at least $2 \mathrm{~h}$. The nuclear DNA was stained with $50 \mathrm{nM}$ SYTOX (Molecular Probes, Inc., Leiden, Netherlands) in PBS for 15 min and excess dye was removed by three washes with PBS. Finally, the nuclei were embedded in Mowiol and examined in a Leitz confocal lasermicroscope. The SYTOX/DNA complex has excitation and emission maxima at $504 \mathrm{~nm}$ and $523 \mathrm{~nm}$, respectively.

\section{Detection of nuclease activity}

One dimensional zymogram After separating the proteins by SDSPAGE in $12 \%$ gels containing $100 \mu \mathrm{g} / \mathrm{ml}$ calf thymus DNA, the nucleases were activated by soaking the gels in $40 \mathrm{mM}$ Tris- $\mathrm{HCl}, \mathrm{pH}$ $8.0,5 \mathrm{mM} \mathrm{CaCl}_{2}, 5 \mathrm{mM} \mathrm{MgCl}_{2}, 3 \%$ delipidated milk powder. DNA was stained with ethidium bromide $(0.5 \mu \mathrm{g} / \mathrm{ml})$ and visualised with UV-light. In order to distinguish bands caused by nuclease catalysed DNAdegradation from those due to mere DNA-binding, the zymogram gel shown in Figure $1 \mathrm{~A}$ was soaked in $1 \%$ SDS, extensively washed with $\mathrm{H}_{2} \mathrm{O}$ and subsequently restained with ethidium bromide. Finally the gels were stained with Coomassie brilliant blue.

Two dimensional zymogram Isoelectric focusing (IEF) was performed using the Mini Protean II system (Bio Rad, Munich, Germany). Proteins were separated in a $\mathrm{pH}$ gradient of $3-10$ in the presence of urea according to O'Farrel (1975). Subsequently the gels were cut into stripes, soaked in sample buffer $(62.5 \mathrm{mM}$ Tris-HCl, pH 6.8, 5\% SDS, $30 \mathrm{mM}$ DTE, $4 \mathrm{mg} / \mathrm{ml}$ bromophenol blue) and layered on $12 \%$ SDSpolyacrylamide gels containing $100 \mu \mathrm{g} / \mathrm{ml}$ DNA. The following procedures were as described for 'one dimensional zymogram'.

Photometric assay Activity was estimated by measuring the change of absorbance at $260 \mathrm{~nm}$ using $400 \mu \mathrm{l}$ of a solution containing $50 \mu \mathrm{g} /$ $\mathrm{ml}$ calf thymus DNA as substrate in $10 \mathrm{mM}$ Tris- $\mathrm{HCl}$, $\mathrm{pH} \mathrm{7.6,}$ containing EDTA, $\mathrm{CaCl}_{2}, \mathrm{MgCl}_{2}, \mathrm{MnCl}_{2}$ or $\mathrm{ZnCl}_{2}$ in concentrations as indicated and $100 \mu \mathrm{l}$ partially purified mycoplasma nucleases. One Kunitz unit corresponds to an increase in absorbance at $260 \mathrm{~nm}$ of 0.001/min/ml (Kunitz, 1950).

\section{DNA degradation in isolated nuclei}

$2 \times 10^{5}$ nuclei were pelleted by centrifugation and resuspended in $200 \mu \mathrm{l} 40 \mathrm{mM}$ Tris- $\mathrm{HCl}$, pH 7.6, containing EDTA or $\mathrm{MgCl}_{2} / \mathrm{CaCl}_{2}$ at the concentrations given. After addition of 5-10 $\mu \mathrm{l}$ sample, the mixtures were incubated overnight at room temperature or at $37^{\circ} \mathrm{C}$ as indicated. Proteins were digested by addition of proteinase $\mathrm{K}$ at a final concentration of $0.4 \mathrm{mg} / \mathrm{ml}$. DNA was pelleted with isopropanol, washed with ethanol, dried and separated in 1\% agarose gels in Trisborate-EDTA buffer.

\section{Purification of mycoplasma nucleases by chromatography using a S Sepharose Fast Flow column}

$220 \mathrm{ml}$ serum-free culture supernatant of mycoplasma-infected PaTu 8902 cells was loaded on a $50 \mathrm{ml} \mathrm{S}$ Sepharose Fast Flow column (Pharmacia, Freiburg, Germany) equilibrated with $20 \mathrm{mM}$ Tris-acetate, $\mathrm{pH}$ 7.8. Elution was performed with a linear gradient of $0-1 \mathrm{M} \mathrm{NaCl}$ in $20 \mathrm{mM}$ Tris-acetate, $\mathrm{pH}$ 7.8. About 80 fractions of $10 \mathrm{ml}$ were collected and screened for nuclease activity by the photometric assay and the zymogram technique. Fractions containing high levels of nuclease activity were pooled and concentrated by pressure dialysis in an Amicon cell (Amicon, Witten, Germany).

\section{Production of actin-gelsolin segment 1 complex}

For the production of actin-gelsolin segment 1 complex equimolar amounts of gelsolin segment 1 and skeletal muscle actin (kindly provided by Dr. E. Ballweber, Bochum) were mixed and incubated in buffer $\mathrm{G}$ (5 mM HEPES, pH 7.4, 0.1 mM CaCl $2,0.2 \mathrm{mM} \mathrm{ATP,} 0.2 \mathrm{mM}$ $\mathrm{NaN}_{3}$ ) overnight on ice.

\section{Acknowledgements}

It is a pleasure for us to thank Mrs Anita Jaeger for excellent photographic work and the Deutsche Forschungsgemeinschaft (Bonn-Bad Godesberg) for financial support.

\section{References}

Almendral JM, Sommer D, Macdonald-Bravo H, Burckhardt J, Perera J and Bravo R (1988) Complexity of the early genetic response to growth factors in mouse fibroblasts. Mol. Cell. Biol. 8: 2140-2148

Arends MJ, Morris RG and Wyllie AH (1990) Apoptosis. The role of the endonuclease. Am. J. Pathol. 136: 593-608

Barry MA and Eastman A (1993) Identification of deoxyribonuclease II as an endonuclease involved in apoptosis. Arch. Biochem. Biophys. 300: 440-450

Bradford MM (1976) A rapid and sensitive method for the quantitation of microgram quantities of protein utilizing the principle of protein-dye binding. Anal. Biochem. 72: $248-254$

Bendjennat M, Blanchard A, Loutfi M, Montagnier L and Bahraoui E (1997) Purification and characterization of Mycoplasma penetrans $\mathrm{Ca}^{2+} / \mathrm{Mg}^{2+}$. dependent endonuclease. J. Bacteriol. 179: 2210-2220

Cohen JJ and Duke RC (1984) Glucocorticoid activation of a calcium-dependent endonuclease in thymocyte nuclei leads to cell death. J. Immunol. 132: 38-42

Deng $G$ and Podack ER (1995) Deoxyribonuclease induction in apoptotic cytotoxic T lymphocytes. FASEB J. 9:665-669

Gaido ML and Cidlowski JA (1991) Identification, purification, and characterization of a calcium-dependent endonuclease (NUC18) from apoptotic rat thymocytes. NUC18 is not histone H2B. J. Biol. Chem. 266: $18580-18585$

Gottlieb RA, Nordberg J, Skowronski E and Babior B (1996) Apoptosis induced in Jurkat cells by several agents is preceded by intracellular acidification. Proc. Natl. Acad. Sci. USA 93: 654-658

Hevelone J and Hartman PS (1988) An endonuclease from Caenorhabditis elegans: partial purification and characterization. Biochem. Genet. 26: 447-461

Kawabata H, Anzai N, Masutani H, Yoshida Y and Okuma M (1993) Detection of $\mathrm{Mg}^{2+}$-dependent endonuclease activity in myeloid leukemia cell nuclei capable of producing internucleosomal DNA cleavage. Biochem. Biophys. Res. Commun. 191: 247-254

Kawabata H, Anzai N, Masutani H, Hirama T, Hishita T, Dodo M, Masuda T, Yoshida Y and Okuma M (1997) $\mathrm{Mg}^{2+}$ - or $\mathrm{Mn}^{2+}$-dependent endonuclease activities of human myeloid leukemia cells capable of producing nucleosomal-size DNA fragmentation. Biochem. Biophys. Res. Commun. 233: 133-138

Kunitz M (1950) Crystalline deoxyribonuclease I: Isolation and general properties. Spectrophotometric method for the measurement of deoxyribonuclease activity. J. Gen. Physiol. 39: 349-362

Lang K (1985) Mycoplasmen und Zellkulturen. Biologie in unserer Zeit. 2: 52-61

Lazarides E and Lindberg U (1974) Actin is the naturally occurring inhibitor of deoxyribonuclease I. Proc. Natl. Acad. Sci. USA 71: 4742-4746

Mannherz HG, Barrington Leigh J, Leberman Rand Pfrang H (1975) A specific 1 : 1 Gactin:DNAse i complex formed by the action of DNAase I on F-actin. FEBS Lett. 60: $34-38$

Martin DP, Schmidt RE, DiStefano PS, Lowry OH, Carter JG and Johnson EM Jr (1988) Inhibitors of protein synthesis and RNA synthesis prevent neuronal death caused by nerve growth factor deprivation. J. Cell. Biol. 106: 829-844

Martin SJ, Lennon SV, Bonham AM and Cotter TG (1990) Induction of apoptosis (programmed cell death) in human leukemic $\mathrm{HL}-60$ cells by inhibition of RNA or protein synthesis. J. Immunol. 145: 1859-1867

Martin SJ (1993) Apoptosis: suicide, execution or murder? Trends Cell. Biol. 3: 141 144 
MyGarrity GJ (1982) Detection of mycoplasmal infection of cell cultures. In Advances in cell cultures, Maramorosch K, ed. (New York: Academic Press) pp. 99-131

McGarrity GJ, Kotani H and Butler GH (1992) Mycoplasmas and tissue culture cells. In Mycoplasmas: Molecular Biology and Pathogenesis, Maniloff J, McElhaney NR, Finch LR and Baseman JB, eds (Washington D.C.: American Society for Microbiology) pp. 445-454

Minion FC and Goguen JD (1986) Identification and preliminary characterization of external membrane-bound nuclease activities in Mycoplasma pulmonis. Infect. Immun. 51: 352-354

Minion FC, Jarvill-Taylor KJ, Billings DE and Tigges E (1993) Membrane-associated nuclease activities in mycoplasmas. J. Bacteriol. 175: 7842-7847

Oberhammer F, Wilson JW, Dive C, Morris ID, Hickman JA, Wakeling AE, Walker PR and Sikorska M (1993) Apoptotic death in epithelial cells: cleavage of DNA to 300 and/or $50 \mathrm{~kb}$ fragments prior to or in the absence of internucleosomal fragmentation. EMBO J. 12: 3679-3684

O'Farrell PH (1975) High resolution two-dimensional gelelectrophoresis of proteins. J. Biol. Chem. 250: 4007-4021

Otto AM, Paddenberg R, Schubert S and Mannherz HG (1996) Cell-cycle arrest, micronucleus formation, and cell death in growth inhibition of MCF-7 breast cancer cells by tamoxifen and cisplatin. J. Cancer Res. Clin. Oncol. 122: $603-$ 612

Paddenberg R, Wulf S, Weber A, Heimann P, Beck LA and Mannherz HG (1996) Internucleosomal DNA fragmentation in cultured cells under conditions reported to induce apoptosis may be caused by mycoplasma endonucleases. Eur. J. Cell. Biol. 69: 105-119

Peitsch MC, Polzar B, Stephan H, Crompton T, MacDonald HR, Mannherz HG and Tschopp J (1993) Characterization of the endogenous deoxyribonuclease involved in nuclear DNA degradation during apoptosis (programmed cell death). EMBO J. 12: $371-377$

Pollack JD and Hoffmann PJ (1982) Properties of the nucleases of mollicutes. J. Bacteriol. 152: $538-541$

Rauch F, Polzar B, Stephan H, Zanotti S, Paddenberg R and Mannherz HG (1997) Androgen ablation leads to an upregulation and intranuclear accumulation of deoxyribonuclease I in rat prostate epithelial cells paralleling their apoptotic elimination. J. Cell. Biol. 137: 909-923
Rawadi G and Dussurget $O$ (1995) Advances in PCR-based detection of mycoplasmas contaminating cell cultures. PCR Methods Appl. 4: 199-208

Razin S and Jacobs E (1992) Mycoplasma adhesion. J. Gen. Microbiol. 138: 407422

Rottem S and Barile MF (1993) Beware of mycoplasma. Tib. Tech. 11: 143-151

Shiokawa D, Ohyama H, Yamada T, Takahashi Kand Tanuma S (1994) Identification of an endonuclease responsible for apoptosis in rat thymocytes. Eur. J.Biochem. 226: $23-30$

Sokolova IA, Cowan $\mathrm{KH}$ and Schneider $\mathrm{E}$ (1995) $\mathrm{Ca}^{2+} / \mathrm{Mg}^{2+}$-dependent endonuclease activation is an early event in VP-16-induced apoptosis of human breast cancer MCF7 cells in vitro. Biochim. Biophys. Acta. 1266: $135-$ 142

Tyron VV and Baseman JB (1992) Pathogenic determinants and mechanisms. In Mycoplasmas: Molecular Biology and Pathogenesis, Maniloff J, McElhaney NR, Finch LR and Baseman JB, eds. (Washington D.C.: American Society for Microbiology) pp. 457-471

Ucker DS, Obermiller PS, Eckhart W, Apgar JR, Berger NA and Meyers J (1992) Genome digestion is a dispensable consequence of physiological cell death mediated by cytotoxic T lymphocytes. Mol. Cell. Biol. 12: 3060-3069

Watanabe H, Kanbe K, Shinozaki T, Hoshino H and Chigira M (1995) Apoptosis of a fibrosarcoma induced by protein-free culture involves DNA cleavage to large fragments but not internucleosomal fragmentation. Int. J. Cancer 62: 191-198

Wyllie AH, Kerr JF and Currie AR (1980) Cell death: the significance of apoptosis. Int. Rev. Cytol. 68: 251-306

Yasuda T, Mizuta K, Ikehara Y, Kishi K (1989) Genetic analysis of human deoxyribonuclease I by immunoblotting and the zymogram method following isoelectric focusing. Anal. Biochem. 183: 84-88

Zhang C, Robertson MJ and Schlossman SF (1995) A triplet of nuclease proteins (NP42-50) is activated in human Jurkat cells undergoing apoptosis. Cell. Immunol. 165: 161-167 